\title{
Comparison of Teacher Training Programs in terms of Attitudes towards Teaching Profession and Teacher Self-Efficacy Perceptions: A Meta-Analysis
}

\author{
Ismail Yelpaze (iD) 1,*, Levent Yakar (iD)
}

${ }^{1}$ Kahramanmaraş Sütçü İmam University, Faculty of Education, Department of Educational Sciences, Turkey

\author{
ARTICLE HISTORY \\ Received: March 19, 2020 \\ Revised: July 3, 2020 \\ Accepted: Sep. 10, 2020

\section{KEYWORDS} \\ Teacher training program, \\ Teacher self-efficacy \\ perception, \\ Teaching profession \\ attitudes
}

\begin{abstract}
The aim of this study is to conduct a meta-analysis of studies comparing teacher training programs in terms of attitude towards teaching profession and perception of teacher self-efficacy. For this purpose, the results of the study comparing the faculty of education (FE) and other teacher training programs/faculties were searched and recorded separately for both subjects. A total of 36 studies were recorded in accordance with the criteria, and 27 of these studies were used for the attitude towards teaching profession and 24 for the teacher selfefficacy perceptions. According to the results of the meta-analysis conducted according to the random effect model, teacher candidates in FE have more negative attitude and lower self-efficiency than ones in other teacher training faculties/programs. The difference in both subjects was found to be weak but not statistically significant. The effect size of most common comparison, FEPedagogical Formation Certificate Program comparisons in the literature is similar to the general effect. It is concluded that faculties of education whose main purpose is to train teachers do not increase these features of their students sufficiently.
\end{abstract}

\section{INTRODUCTION}

The main purpose of education is to prepare human beings for life. In order to achieve this goal in formal education, all stakeholders in education need to work effectively. The most important factor for the education system -which includes students, teachers, administrators, education programs, family, other personnel, buildings, equipment and environment- is the teacher (Kartal, Temelli, \& Şahin, 2019), and its influence is higher than other factors (Çapa \& Çil, 2000). The teacher, is also the most important player in the creation of qualified manpower for the development of the country, preparing the individual for life and ensuring social peace (Kaya, 2001; Özden, 1999). All citizens of the country are necessarily included in the education system and spend time together with teachers for 12 years period when they are most open to learning and self-development. This shows the important role of the teacher in the training of individuals.

There are a lot of studies investigating that the teacher has an important effect on the success of the student (Canales \& Maldonado, 2018; Çelik, Örenoğlu Toraman, \& Çelik, 2018). Teachers responsible for the training of qualified individuals are expected to have various qualifications, too. These qualifications can only be gained by a planned education. Therefore, the importance of training qualified teachers is quite clear. The Ministry of National Education

${ }^{*}$ CONTACT: İsmail YELPAZE \ismailyelpaze@gmail.com Faculty of Education, Department of Educational Sciences, Turkey 
(MoNE, 2017) has identified three main competence of the teaching profession; professional knowledge, professional skill and attitude and values. As a result, teachers are expected to have knowledge and skills related to their field and adopt the values of the profession and gain a positive attitude.

It is known that teacher candidates' attitudes affect their professional success as well as their professional knowledge and skills (Doğan, 2013; İlter, 2009). Attitude is defined as the tendency of the individual to like-dislike an event, situation or object (Kenrick, Neuberg, \& Cialdini, 2005) or the individual's emotion-thought-behavioral tendencies towards an object (Kağıtçıbaş1, 2013). Since attitudes include behavioral tendencies towards attitude objects (Sakall1, 2001), a strong and positive attitude can direct the behavior of an individual. Thus, it is seen that attitudes of teachers towards their professions are very determinant in directing their professional behaviors (Özkan, 2012), and a positive attitude provides success and satisfaction in the profession (Recepoğlu, 2013). Teachers who have a positive attitude towards their profession commit with a passion to profession and are more motivated to fulfill the requirements of the profession (Durmuşoğlu, Yanık, \& Akkoyunlu, 2009). For this reason, it is important to determine the attitudes of teacher candidates towards the profession in predicting their success and satisfaction in the profession.

Along with attitude towards the profession, self-efficacy perception about the profession is also another factor affecting the quality of the teacher. The concept of self-efficacy, first introduced by Bandura in 1977, is defined as the subjective perception of the individual that he can successfully overcome this challenge (as cited in Senemoğlu, 2012). Since the perception of teaching self-efficacy is a more subjective topic, its definition is defined as the subjective assessment of the teachers that they have the skills to perform the tasks related to the teaching needs specific to their fields (Tschannen-Moran, Woolfolk Hoy, \& Hoy, 1998). Self-efficacy perception not only determines the way of thinking, emotions and behavior of individuals but also affects their resilience in the face of difficulties (Bandura, 1997). For this reason, teachers' perceptions of professional efficacy affect their success and professional satisfaction (Karabiyık \& Güvenlikaz, 2014).

Although the reasons such as low socioeconomic status and negative individual characteristics of students affect learning negatively (Kartal, Temelli, \& Şahin, 2019), teachers with high teaching self-efficacy can turn students' learning in a positive way (Tucker et al., 2005). Because teachers with high teaching self-efficacy are eager to plan and implement their plans, they are open to new thoughts to meet the needs of students, and they try and research new methods (Gülebağlan, 2003). On the other hand, if teacher candidates have low teacher selfefficacy they have more difficulties when they begin the profession (Arastaman, 2013; Brown, Lee, \& Collins, 2015). As a result, it seems important that teacher training programs should aim to ensure that teacher candidates not only have academic knowledge but also gain positive attitudes towards the profession and have realistically high teacher self-efficacy.

The majority of teacher training programs in Turkey are located in the education faculties of universities. However, teacher candidates who graduated from the Non-Thesis Master Program in Secondary Education Teaching (NTMP) were able to become a teacher until 2008. Nowadays, those who graduate from faculties other than education faculty can become teachers if they have graduated from the pedagogical formation certificate program (PFCP) that is a follow-up of NTMP (Akdemir, 2013). In addition, students of the faculty of theology (FT) and the faculty of science and literature (FSL) can become teachers if they take pedagogical formation courses. In addition to these programs, graduates from the faculty of technical education (FTE) and teaching programs in physical education and sports school (PESS) can also become teachers. Programs mentioned above will be referred to as teacher training programs hereinafter. Since teacher training programs play an important role in shaping the 
teacher candidates' beliefs and attitudes towards the profession (Hong \& Greene, 2011), it can be thought that the professional attitudes and teacher self-efficacy perceptions of the teacher candidates studying in different programs will also differ.

Since the importance of attitudes towards teaching profession and perceptions of teacher selfefficacy is realized by researchers, there are a lot of studies in the literature comparing teacher self-efficacy perceptions and attitudes towards the profession of teacher candidates studying in different programs. However, these studies investigated different results. For example, in the study of Dadand1, Kalyon, and Yazıc1 (2016), teacher candidates in the faculty of education have a more positive attitude towards the profession, while in the study of Bağçeci, Yıldırım, Kara, and Keskinpalta (2015), students at pedagogical formation certificate program have a more positive professional attitude. Similarly, in the study of Yaşar-Ekici (2017), students at pedagogical formation certificate program have higher teacher self-efficacy perception, while in Çetin's (2017) study, students of education faculty have higher teacher self-efficacy perception. These different results cause confusion and uncertainty. Thus, it is necessary to reveal which group is in favor of attitudes and self-efficacy perceptions. Because singular studies are carried out with limited samples and at limited times, they have limitations to provide comprehensive information about which teacher candidate's professional attitude and self-efficacy perception is more positive. Besides, even if the difference is significant, interpretation of the results only on statistical significance can be misleading (Cohen, 1990) and it is necessary to investigate whether statistical significance represents practical significance (Ellis, 2010).

Meta-analysis is one of the methods to overcome these limitations. Through meta-analysis, studies with different findings can be presented in an effective and holistic way, taking into account the sample sizes and undergoing a systematic evaluation (Lipsey \& Wilson, 2001). In fact, there are meta-analysis studies examining the professional attitudes of teachers. When the related meta-analysis studies are examined, it is seen that they are related to comparison of attitude towards teaching profession in terms of gender (Erdamar, Aytaç, Türk, \& Arseven, 2016; Tuncer, 2016), comparison of teacher self-efficacy in terms of gender (Çelik, KoçErdamar, \& Toraman, 2016) and comparison of attitude towards teaching profession in terms of education and other faculties (Atalmış \& Köse, 2018). When these studies are analyzed, it is seen that there is no detailed comparison of teacher self-efficacy and attitude towards the teaching profession in terms of each teacher training program. With this study, a step is taken to fill these gaps in the literature. By this means, it is expected that the attitudes towards teaching profession and perceptions of teacher self-efficacy are in favor of which group is more reliable, so there will be some light shed on this uncertainty. Last but not least, teacher training programs will be able to see their own levels of teacher candidates' perception of self-efficacy and attitude towards the teaching. Also, they can benefit from the findings of this study in assessing their educational outcomes.

Consequently, the aim of this study is to conduct meta-analysis of studies comparing teacher training programs in terms of teacher candidates' attitude towards teaching profession and perception of teacher self-efficacy.

\section{METHOD}

This study aims to present the findings in a holistic way by bringing together the relevant studies in the field. In order to achieve this aim, the research was carried out by meta-analysis. Metaanalysis, which means collecting analyzes, is a method based on achieving a general result by combining the results obtained from different studies (Dinçer, 2014). From another perspective, meta-analysis can be seen as a literature review based on quantitative data. Accordingly, meta- 
analysis can be expressed as the statistical analysis of the results of numerous analyzes obtained from individual studies in order to integrate the findings (Glass, 1976).

\subsection{Data Collection Procedure}

Since the study focused on two main issues related to teaching such as attitude towards teaching profession and teacher self-efficacy perception, the data were collected in each subject in separate processes. The processing steps for each subject are as follows; Keywords of "öğretmenlik mesleğine yönelik tutum karşılaştırma" (comparison of attitude towards teaching profession), "öğretmenlik tutum karşılaştırma" (comparison of attitude of teaching), "öğretmen öz-yeterlik algısı karşılaştırma" (comparison of teacher self-efficacy perception), "öğretmen öz-yeterlik karşılaştırma" (comparison of teacher self-efficacy), "attitude towards teaching comparison" and "teacher self-efficacy comparison" were scanned in databases of Google Scholar, Turkish Academic Network And Information Center (Ulakbim) and Turkish Council of Higher Education (YÖK) National thesis center, in January 2018 - August 2019, two times. Among the reached published and unpublished studies which meet the following criteria were included in the meta-analysis process.

1. The study should be related to teacher candidates' attitude towards teaching profession and / or perception of teacher self-efficacy. (Studies with general self-efficacy perception level were not taken into consideration.)

2. The study must include data from at least one of the relevant subjects of pre-service teachers who graduated or studying at the Faculty of Education and pre-service teachers who graduated or studying at the other departments

3. The study must be conducted on pre-service teachers. (Studies on teachers, appointed candidate teachers or undergraduate students or alumni who are not pre-service teachers were not taken into consideration.)

4. Study must present sample sizes, averages and standard deviations/t score or U values and sample sizes values that can be transformed to effect size.

As a result of the surveys, a total of 40 studies which meet the above mentioned criteria were reached. As the U-values were given only for the subscales in one of the studies, and only the item analyzes were given in two of them, they were excluded from the final study since they could not be used in the meta-analysis when the re-detailed examinations. And, one study was excluded from the final study list due to lack of validity and reliability evidence of the used scale and analysis was conducted with 36 studies.

Data were recorded independently by both researchers. After the data were recorded, crosschecks were made and agreed data was decided to take final study list. The name of the study, the name of the researchers, the year of publication, the type of publication, the publisher, the name of the programs being compared, as well as the corresponding scale mean scores, sample sizes and standard deviations or $t$ values of the pre-service teachers in each program were recorded. For some studies, sample sizes and U values were recorded. The number and sample size of the studies according to the subject, type of publication and comparison units are presented in Table 1.

In Table 1, the number of the studies which were performed in the meta-analysis and general characteristics of studies are presented. A total of $24(17+7)$ studies were about attitudes towards teaching profession and $19(12+7)$ studies were about teacher self-efficacy perception. In one of these studies, there were $4 \mathrm{FE} /$ Other comparisons that contain research results on both subjects. There were $2 \mathrm{FE} /$ Other comparisons in 2 studies which were about teacher selfefficacy study. Thus, 27 comparisons were made for attitudes towards the teaching profession and 24 comparisons in teacher self-efficacy perception were subjected to meta-analysis. 
Table 1. The number of studies involved in Meta-analysis

\begin{tabular}{|c|c|c|c|c|c|}
\hline Subject & $\begin{array}{l}\text { Comparison } \\
\text { Program }\end{array}$ & Article & Thesis & $\begin{array}{l}\text { Book } \\
\text { Section }\end{array}$ & Total \\
\hline \multirow{6}{*}{$\begin{array}{l}\text { Attitude } \\
\text { Profession }\end{array}$} & PFCP (a) & $8(2679)$ & $1(1116)$ & & $9(3795)$ \\
\hline & FSL (b) & $3(403)$ & & & $3(403)$ \\
\hline & FT (c) & $1(273)$ & & & $1(273)$ \\
\hline & PESS (d) & $2(523)$ & & & $2(523)$ \\
\hline & NTMP & $2(513)$ & & & $2(513)$ \\
\hline & Total & $16(4391)$ & 1(1116) & & $17(5507)$ \\
\hline \multirow{7}{*}{ Teacher Self-Efficacy Perception } & PFCP & $6(2035)$ & & & $6(2035)$ \\
\hline & FSL & $1(338)$ & & & $1(338)$ \\
\hline & PESS & $1(411)$ & & & $1(411)$ \\
\hline & FTE & $1(495)$ & & & $1(495)$ \\
\hline & NTMP & & $1(496)$ & & 1(496) \\
\hline & PFCP\&FSL & $1(407)$ & $1(854)$ & & $2(1261)$ \\
\hline & Total & $10(3686)$ & $2(1350)$ & & $12(5036)$ \\
\hline \multirow{5}{*}{ Both } & PFCP & $3(1084)$ & & $1(452)$ & $4(1536)$ \\
\hline & PESS & $1(411)$ & & & $1(411)$ \\
\hline & (a), (b), (c), (d) & $1(786)$ & & & $1(786)$ \\
\hline & FTE & $1(250)$ & & & $1(250)$ \\
\hline & Total & $6(2531)$ & & $1(452)$ & $7(2983)$ \\
\hline Total & & $32(10608)$ & $3(2466)$ & $1(452)$ & $36(13526)$ \\
\hline
\end{tabular}

PFCP (a): Pedagogical Formation Certificate Program, FSL (b): Faculty of Science\&Letter, FT (c): Faculty of Theology, PESS (d): Physical Education and Sports Scholl, NTMP: Non-Thesis Master Program, FTE: Faculty of Technical Education

Sample sizes of the studies used in meta-analysis are given in brackets in Table 1. When the sample sizes are examined, $8490(5507+2983)$ pre-service teachers constitute the total sample in attitudes towards teaching profession studies, while $8019(5036+2983)$ pre-service teachers constitute the total sample in the teacher self-efficacy studies.

\subsection{Data Analysis}

The data were analyzed by meta-analysis. Comprehensive Meta-Analysis Version 3 (CMA) software designed for meta-analysis was used for data analysis. In order to analyze the data, some processes were performed before analysis. In the literature search, some studies reported $U$ value in comparison findings. Since the $U$ value cannot be used directly in the used software, the U value was converted to Cohen's effect size d (Lenhard \& Lenhard, 2016). Another process performed before the data analysis was to combine the subscale findings. There are many scales for attitudes towards teacher profession and perception of teacher self-efficacy used in the studies and these scales contain different names and number of dimensions. In order to bring the studies together, only the scale total scores were taken into consideration. In the studies which did not include the scale total score, the subscale values were combined and statistics related to the scale total score were calculated. In this study, a meta-analysis was performed for each of the two subjects.

The most important statistic is effect size in meta-analysis (Dinçer, 2014). It is stated that the effect size must be reported together with the $\mathrm{p}$ value that reveals the difference of the effect size statistics from zero (Sullivan \& Feinn, 2012) and even the effect size is more important than the p value (Borenstein, Hedges, Higgins, \& Rothstein, 2009). For this reason, in the 
expression and interpretation of the findings in the study, firstly the effect size and then the $p$ value were taken into consideration.

There are different effect sizes such as Cohen's d, Hedge's g or Glass's $\Delta$ for the overall effect that results from meta-analysis. In some cases, these statistics may have superiorities to another. It is stated that Cohen's d statistic provides accurate result if the number of samples in the studies is over 20. (Lipsey \& Wilson, 2001) Cohen's d statistic was used in this study because the samples of all the studies included were above 20. Cohen's effect size ranges and their meanings are given in Table 2 (Cohen, Manion, \& Morrison, 2007).

Table 2. Cohen's Effect Size Ranges and Their Meanings

\begin{tabular}{ll}
\hline Cohen's d & Meaning \\
\hline $0-0.20$ & Weak Effect \\
$0.21-0.50$ & Modest Effect \\
$0.50-1.00$ & Moderate Effect \\
$>1.00$ & Strong Effect \\
\hline
\end{tabular}

Another case that should be decided before presenting the meta-analysis findings is which of the fixed effects and random effects models will be used in the calculation of the overall effect. The fixed effect model is based on the assumption that all the studies analyzed have the same effect and the difference between the results of studies is due to the sampling error in the studies. The biggest difference of the random effect model from the fixed effect model is that it is based on the assumption that the studies may have different effects (Üstün \& Eryılmaz, 2014). Providing the source of variance correctly will help in choosing the right model. Considering the years of the studies, the university in which they were conducted, and the units which comparison was made, the use of random effects method was found to be a more appropriate option in the analysis for overall effect calculation. The results of the heterogeneity test were also taken into consideration in the model selection (Yıldırım, Çırak-Kurt, \& Şen, 2019). If the $\mathrm{Q}$ statistic is greater than the chi-square value of $\mathrm{p}=0.05$ at the relevant degree of freedom, it indicates heterogeneity. Another statistic in this area is $I^{2}$, when $I^{2}$ value is 25,50,75; it indicates low, medium and high heterogeneity, respectively (Higgins, Thompson, Deeks, \& Altman, 2003). In the analyzes in which the effect of the sub-groups was analyzed via sub-group variable, random effect model was used between sub-groups and a fixed effect model was used within group. This method is called a mixed effect model (Borenstein, Hedges, Higgins, \& Rothstein, 2013).

Another statistic that comes to the fore in meta-analysis is publication bias. Publication bias can be expressed as the literature bias due to the fact that the probability of publication of studies that are not statistically significant or have low effect size is lower than the probability of publication of studies with significant differences or have large effect size (Borenstein et al., 2013). There are several reasons of publication bias that should be considered in meta-analysis. In this study, detailed scans were carried out to prevent bias that may occur in the literature review, and the studies to be analyzed were selected with consensus. In addition, unpublished master's thesis and doctoral dissertation were also included to minimize the effect of publication bias on the results of meta-analysis. Publication bias analysis was carried out with funnel plot, Duval and Tweedie's (2000a; 2000b) trim and fill method and Egger's linear regression methods (Egger, Davey Smith, Schneider, \& Minder, 1997).

In order to investigate the possible publication bias in the literature, the funnel graph in which individual studies represented as a point, was examined. The points in the funnel graph are shown at the intersection of the horizontal plane corresponding to the effect size of the individual study and the vertical plane corresponding to its standard error. The funnel graph has 
a vertical line extending from the overall effect size calculated in the analysis. The fact that the points representing the individual studies have a symmetrical appearance around this vertical line contains an opinion that there is no publication bias.

Another statistical method used in publication bias is the trim and fill method of Duval and Tweedie (2000a, 2000b). In this method, the effect size is calculated again by subtracting the point representing the individual study located far from the funnel graph. Trim and fill method is a repetitive process based on the funnel graph becoming symmetrical around the new effect size. Subtraction also reduces the variance while regulating the effect size. In order to prevent this situation, the studies are re-added to the analysis and a mirror image is added to the funnel for these studies (Bakioğlu \& Göktaş, 2018). The small difference between the original effect size and the effect size obtained with the trim and fill method of Duval and Tweedie indicates that there is no publication bias.

From the point of view of revealing evidence of bias, the funnel plot method is based entirely, and the trim and fill method of Duval and Tweedie is partially based on visual evidence. Therefore, it can produce subjective results. To overcome this limitation, Egger's linear regression method, which examines statistical bias, was also used. This method is based on the model that contains the regression of the standard normal deviation of the studies against the certainty of this value. For a symmetrical funnel plot according to the model, the regression line obtained from the studies is expected to extend linearly through the origin. The non-significance of the $p$ value obtained from the method $(>0.05)$ indicates that the studies are linearly aligned and there is no bias (Egger, Davey Smith, Schneider, \& Minder, 1997).

In the literature search, it was seen that there were six different teacher training programs compared with FE. The fact that the results of the meta-analysis are generally considered as FE / Other comparison without considering these differences will not be sufficient to elaborate the results. In order to fully understand the direction and strength of the possible differences in different program comparisons, each teacher training program was used as a sub-groups variable. Thus, a process for explaining a source of variance between studies was performed (Borenstein, Hedges, Higgins, \& Rothstein, 2010). Due to the low number of studies in some subgroups, the number of individuals included in the studies was low, and the effect size of these subgroups caused the standard error to be high. Therefore, findings accompanied by standard errors are discussed.

\section{FINDINGS}

In this section, first of all, the findings of the meta-analysis for attitude towards teaching profession will be given. The overall effect size and heterogeneity values of all studies related to attitude towards teaching profession included in the research were calculated. The results are presented in Table 3.

According to the fixed effect model given in Table 3, $Q$ statistics were found as 143.243 from the heterogeneity results obtained. Since this value is higher than $38.885 Q$ value in 26 degrees of freedom in the Chi-square table, it can be said that the studies contain heterogeneity. When the $I^{2}$ statistics are examined, high heterogeneity is observed. When these statistics are taken into consideration, it can be said that the studies are highly heterogeneous. In addition, since the distribution of the effect sizes in Figure 1 shows the difference between the studies, it was decided that the random effect model is suitable for the attitude towards to teaching profession. 
Table 3. Overall effect sizes and heterogeneity results for attitude towards teaching profession

\begin{tabular}{|c|c|c|c|c|c|c|c|c|c|c|}
\hline \multirow{2}{*}{ Model } & \multirow{2}{*}{$\mathrm{N}$} & \multirow{2}{*}{ ES } & \multirow{2}{*}{ SE } & \multicolumn{2}{|c|}{$95 \%$ CI. } & \multirow{2}{*}{ Z } & \multirow{2}{*}{$p$} & \multirow{2}{*}{$\mathrm{df}$} & \multirow{2}{*}{$Q$} & \multirow{2}{*}{$I^{2}$} \\
\hline & & & & Lower & Upper & & & & & \\
\hline Fixed & 27 & -0.051 & 0.023 & -0.096 & -0.006 & -2.221 & 0.026 & 26 & 143.243 & 81.84 \\
\hline Random & 27 & -0.062 & 0.055 & -0.171 & 0.046 & -1.127 & 0.260 & & & \\
\hline
\end{tabular}

The overall effect size of the random effect model for the attitude towards teaching profession is -0.062 . This value appears to indicate weak effect. Since value is close to 0 , it can be said that the overall effect against FE is negligible in FE/Other comparisons. When the significance of the effect size, which is of secondary importance after the effect size, was considered, the effect was not significant ( $p>0.05$ ). The forest graph showing the effect size of individual study and its weight in all studies is presented in Figure 1.

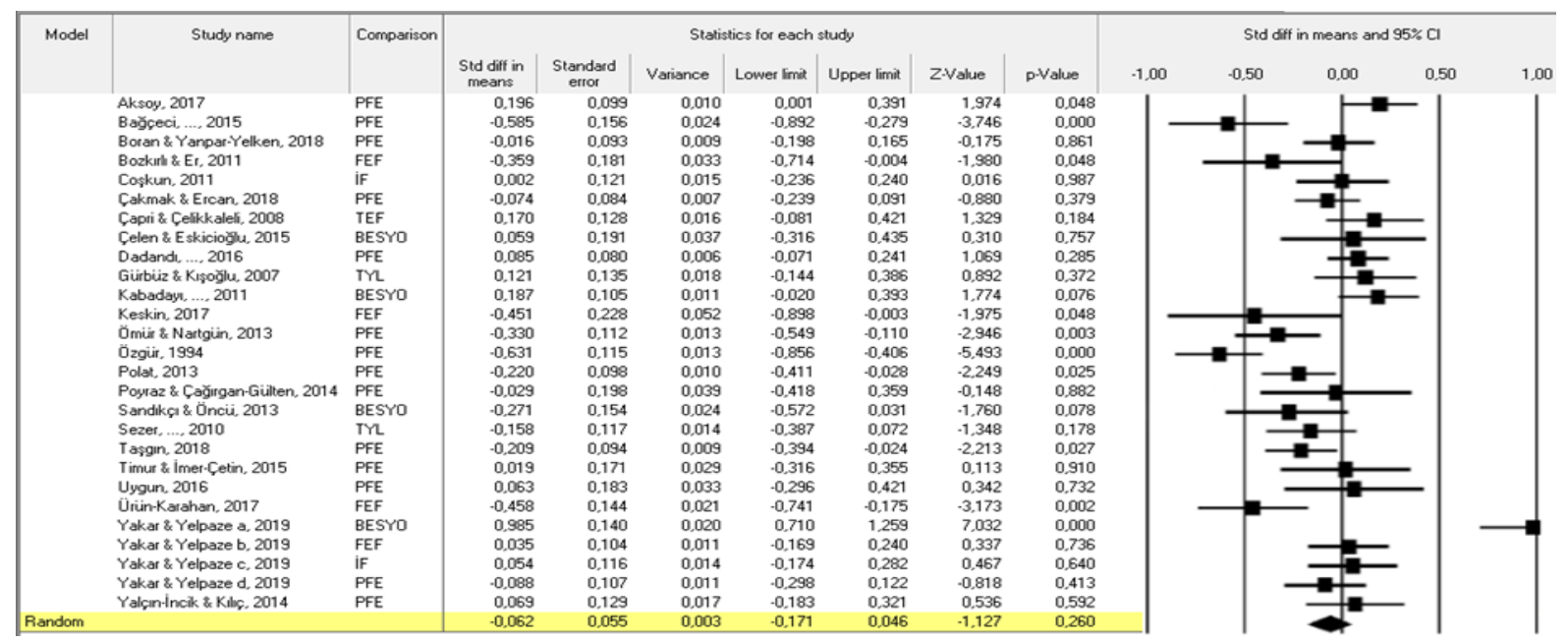

Figure 1. The forest graph showing the effect size of individual study about attitude towards teaching profession

The squares on the right in Figure 1 represent the effect size of the individual study and the line adjacent to the square represents the upper and lower limits of the effect size in the $95 \%$ confidence interval. The weight of the individual work in the overall effect size is represented by the area of the square concerned. The rhombus under the graph shows the overall effect size of the studies.

When the values of the individual studies on the left side of Figure 1 are examined, the effect sizes of the studies vary between -0.631 and 0.985 . Positive values indicate the effect size in favor of FE. Accordingly, the effect size of 27 studies is 13 in favor of FE and 14 in against FE. Subgroups effect sizes for attitude towards the teaching profession for each program compared with FE in order to investigate the source of the variance seen between studies are given in Table 4. 
Table 4. Attitudes towards teaching profession in terms of compared programs

\begin{tabular}{lcccccccccc}
\hline \multirow{2}{*}{ Program } & \multirow{2}{*}{$\mathrm{N}$} & \multirow{2}{*}{ ES } & SE & \multicolumn{2}{c}{$95 \%$ CI } & \multirow{2}{*}{ Z } & $p$ & df & $Q$ & $p$ \\
\hline PESS & 4 & 0.244 & 0.262 & -0.269 & 0.758 & 0.93 & 0.351 & & & \\
FSL & 4 & -0.282 & 0.145 & -0.566 & 0.002 & -1.95 & 0.052 & & & \\
FT & 2 & 0.029 & 0.084 & -0.135 & 0.194 & 0.35 & 0.727 & & & \\
PFCP & 14 & -0.125 & 0.063 & -0.248 & -0.001 & -1.98 & 0.048 & & & \\
FTE & 1 & 0.170 & 0.128 & -0.081 & 0.421 & 1.33 & 0.184 & & & \\
NTMP & 2 & -0.027 & 0.139 & -0.299 & 0.246 & -0.19 & 0.847 & & & \\
Total & 27 & -0.049 & 0.042 & -0.132 & 0.033 & & & 5 & 9.1 & 0.105 \\
\hline
\end{tabular}

Analysis results which were analyzed according to the mixed effect model shown in Table 4; it is seen that the effect sizes calculated for 6 different programs vary between -0.282 and 0.244 . Three of these effect sizes are in favor of FE and 3 of them are against. In FE / PFCP comparison, the effect size was found to be weak and statistically significant in favor of PFCP. The effect sizes seen in other comparisons were not statistically significant. In the comparison program which is the mediator variable, FE / FSL comparison with the highest effect size was also against the $\mathrm{FE}$ and the effect size was low and very close to the statistical significance level. When the FE / PESS comparisons are examined, it was found that the pre-service teachers who are trained in FE have a more positive attitude towards teaching profession, the effect size of this difference is low, but it is not statistically significant.

When the effect of using different programs as sub-group variable on the heterogeneity it is found that $Q$ value does not reach the value of 11.07 which is $X^{2}$ value of 5 degrees of freedom. Therefore, the comparison of different programs did not make a significant contribution to the variance $(p>0.05)$.

Figure $2 \mathrm{a}$ shows the funnel graph, while $2 \mathrm{~b}$ shows funnel graph for trim and fill method for revealing publication bias in the attitudes towards teaching profession studies included in the meta-analysis.

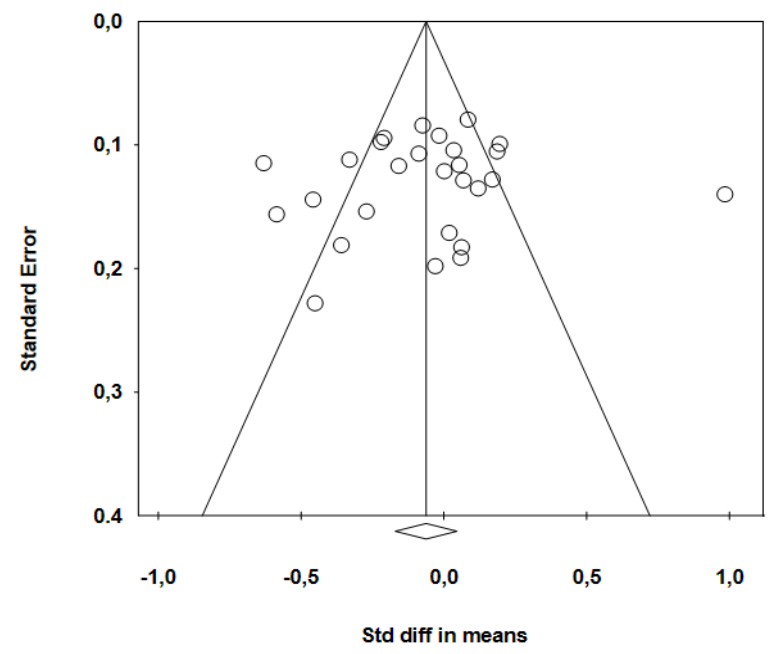

Figure 2a. Attitude towards teaching profession funnel graph

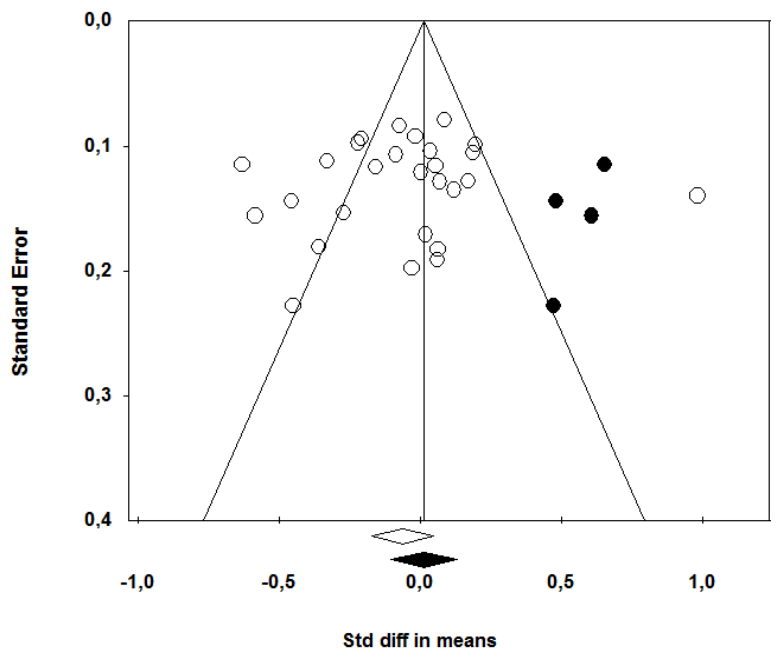

Figure 2b. Attitude towards teaching profession funnel graph for trim and fill method 
In Figure 2a, the effect sizes of the studies about the attitude towards the teaching profession and their standard errors are represented by circles. It is seen that the expected symmetrical distribution is partially achieved. It is seen that the effect sizes of the studies which favor of FE are smaller and closer to each other compared to the studies against FE, which prevents the appearance of full symmetry. For this reason, Figure 2 a cannot provide complete information about publication bias.

The black dots in Figure $2 \mathrm{~b}$ represent the publications that must be added to achieve full symmetry according to the trim and fill method of Duval and Tweedie (2000a, 2000b). The black equilateral quadrangle shows the overall effect size that will occur with the trim and fill method. When Figure $2 \mathrm{~b}$ is analyzed, if 4 publications, in favor of FE, are added to the analysis for corresponding coordinates the funnel plot will be fully symmetrical. The only number to be added to make the 27 studies fully symmetrical is only 4 , which is an indication that the current situation is close to symmetrical distribution. If these 4 studies are added, the overall effect will increase from -0.062 to 0.010 . The fact that the difference is small indicates that there is no publication bias in the studies. Egger's regression method (Egger, Davey Smith, Schneider, \& Minder, 1997), which is another method used in publication bias test, has $t$ value of 0.49 and $p$ value of 0.62. A statistical significance value of $p>0.05$ indicates that there is no bias.

The findings related to the meta-analysis study for teacher self-efficacy perception are given below. Firstly, homogeneity analysis was made to decide which method to use in calculating the effect size. Findings related to this analysis and the overall effect size calculations are presented in Table 5.

Table 5. Overall effect size and heterogeneity results for teacher self-efficacy perception

\begin{tabular}{|c|c|c|c|c|c|c|c|c|c|c|}
\hline \multirow{2}{*}{ Model } & \multirow{2}{*}{$\mathrm{N}$} & \multirow{2}{*}{ ES } & \multirow{2}{*}{$\mathrm{SE}$} & \multicolumn{2}{|c|}{$95 \% \mathrm{CI}$} & \multirow{2}{*}{ Z } & \multirow{2}{*}{$p$} & \multirow{2}{*}{ df } & \multirow{2}{*}{$Q$} & \multirow{2}{*}{$I^{2}$} \\
\hline & & & & Lower & Upper & & & & & \\
\hline Fixed & 4 & -0.035 & 0.023 & -0.081 & 0.010 & -1.535 & 0.125 & 23 & 111.443 & 79.36 \\
\hline Random & 4 & -0.052 & 0.052 & -0.154 & 0.050 & -0.994 & 0.320 & & & \\
\hline
\end{tabular}

According to the fixed effect model given in Table 3, $Q$ statistics were found as 111.443 from the heterogeneity results obtained. Since this value is higher than $35.172 Q$ value in 23 degrees of freedom in the Chi-square table, it can be said that the studies contain heterogeneity. When the $I^{2}$ statistics are examined, high heterogeneity is observed. When these statistics are taken into consideration, it can be said that the studies are highly heterogeneous. In addition, since the distribution of the effect sizes in Figure 3 shows the difference between the studies, it was decided that the random effect model is suitable for the teacher self-efficacy perception.

The overall effect size of the random effect model for teacher self-efficacy perception is -0.052 . This value appears to indicate weak effect. Since value is close to 0 , it can be said that the overall effect against FE is negligible in FE / Other comparisons. When the significance of the effect size, which is of secondary importance after the effect size, was considered, the effect was not significant $(p>0.05)$. The forest graph showing the effect size of individual study and its weight in all studies is presented in Figure 3. 


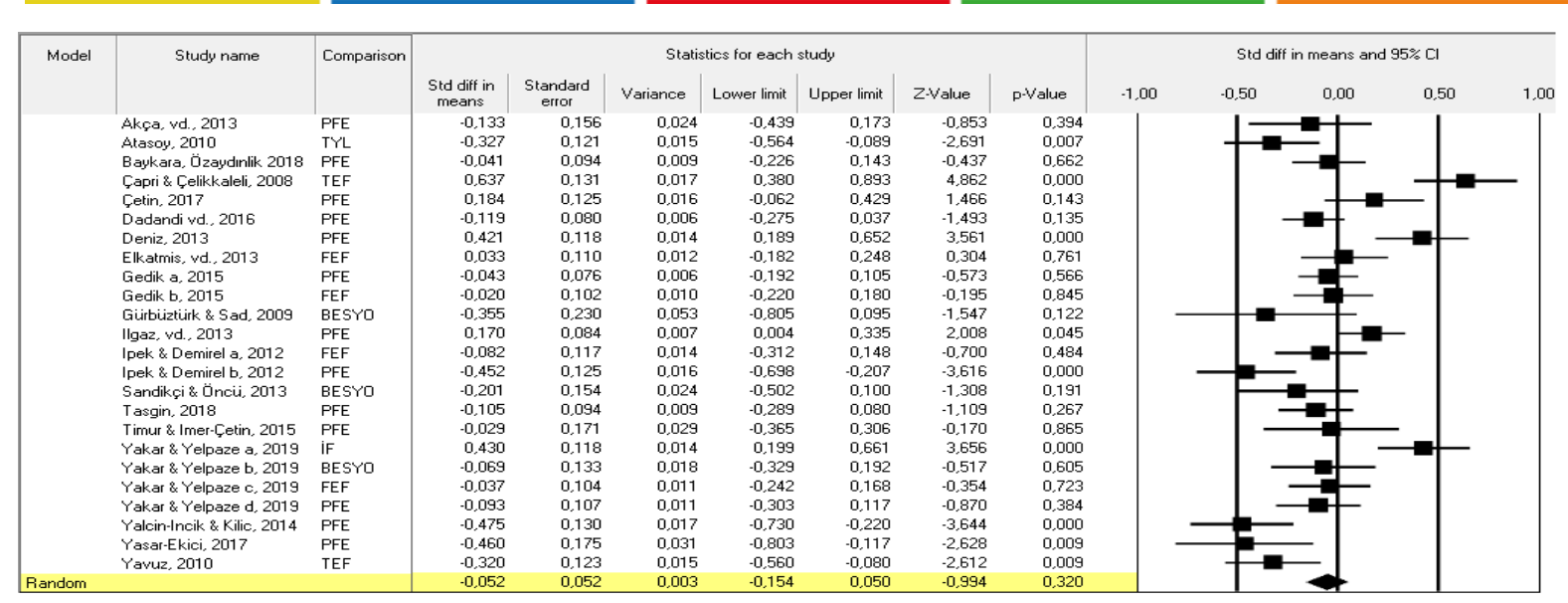

Figure 3. The forest graph showing the effect size of individual study about teacher self-efficacy

As it can be seen in Figure 3, the effect sizes of the studies vary between -0.475 and 0.637. Positive values indicate effect sizes in favor of FE. Accordingly, when the effect sizes of 24 studies are analyzed separately, it is seen that there are results in favor of FE in 6 studies and against FE in 18 studies.

Subgroups effect sizes for teacher self-efficacy perception for each program compared with FE in order to investigate the source of the variance seen between studies are given in Table 6 .

Table 6. Effect sizes of teacher self-efficacy perception

\begin{tabular}{|c|c|c|c|c|c|c|c|c|c|c|}
\hline \multirow{2}{*}{ Program } & \multirow{2}{*}{$\mathrm{N}$} & \multirow{2}{*}{ ES } & \multirow{2}{*}{$\mathrm{SE}$} & \multicolumn{2}{|c|}{$95 \% \mathrm{CI}$} & \multirow{2}{*}{ Z } & \multirow{2}{*}{$p$} & \multirow{2}{*}{$\mathrm{df}$} & \multirow{2}{*}{ Q } & \multirow{2}{*}{$p$} \\
\hline & & & & Lower & Upper & & & & & \\
\hline PESS & 3 & -0.162 & 0.092 & -0.343 & 0.018 & -1.763 & 0.078 & & & \\
\hline FSL & 4 & -0.025 & 0.054 & -0.130 & 0.081 & -0.458 & 0.647 & & & \\
\hline FT & 1 & 0.430 & 0.118 & 0.199 & 0.661 & 3.656 & 0.000 & & & \\
\hline PFCP & 13 & -0.079 & 0.065 & -0.206 & 0.048 & -1.224 & 0.221 & & & \\
\hline FTE & 2 & 0.157 & 0.478 & -0.780 & 1.095 & 0.329 & 0.742 & & & \\
\hline NTMP & 1 & -0.327 & 0.121 & -0.564 & -0.089 & -2.691 & 0.007 & & & \\
\hline Total & 24 & -0.044 & 0.034 & -0.111 & 0.024 & & & 5 & 23.9 & 0.00 \\
\hline
\end{tabular}

When the analysis results made according to the mixed effect model in Table 6 are examined, the effect sizes calculated for six different programs vary between -0.327 and 0.430 . Two of the effect sizes appear to be in favor of FE, while four appear against FE. The FE / PFCP comparison, with the greatest number of studies, showed that the effect size was weak in favor of PFCP and not statistically significant. All of the effect sizes of programs which have more than individual study were found to be weak and were not found statistically significant. It was seen that there was only one study in the FE / FT and FE / NTMP comparisons, and they have highest effect size. Compared to pre-service teachers who are trained in FE, while pre-service teachers who are trained in FT consider themselves inadequate, pre-service teachers who are trained in NTMP education consider themselves more sufficient in terms of professional competence. However, since there was only one study in these subgroups, they were found to have slightly higher standard errors except FTE comparison.

When the effect of using different programs as subgroup variable on the heterogeneity is seen $Q$ value exceeds the value of 11.07 which is $X^{2}$ value of 5 degrees of freedom. Therefore, the comparison of different programs made a significant contribution to the variance $(p<0.01)$.

Figure $4 \mathrm{a}$ shows the funnel graph, $4 \mathrm{~b}$ shows funnel graph for trim and fill method for revealing publication bias in the teacher self-efficacy perception studies included in the meta-analysis. 


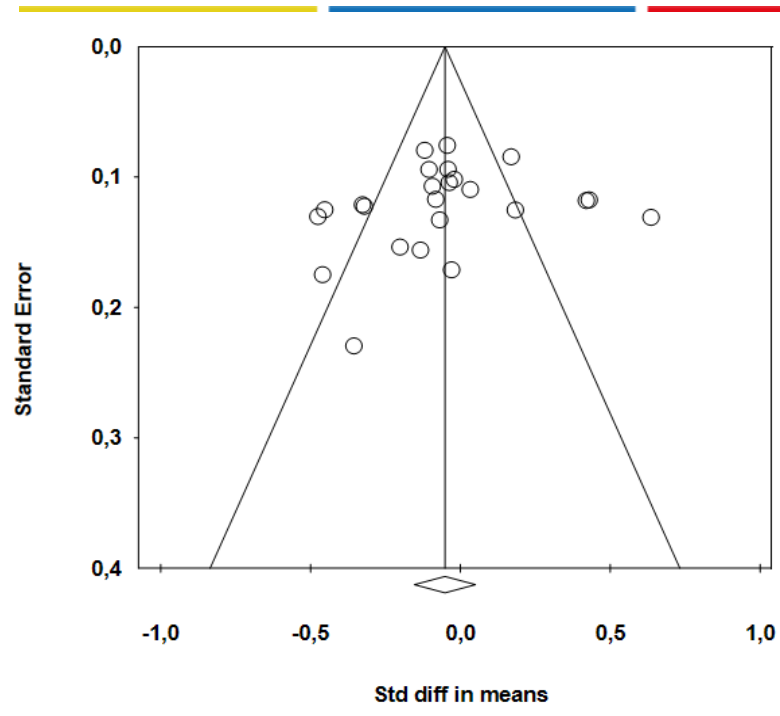

Figure 4a. Teacher self-efficacy perception funnel graph

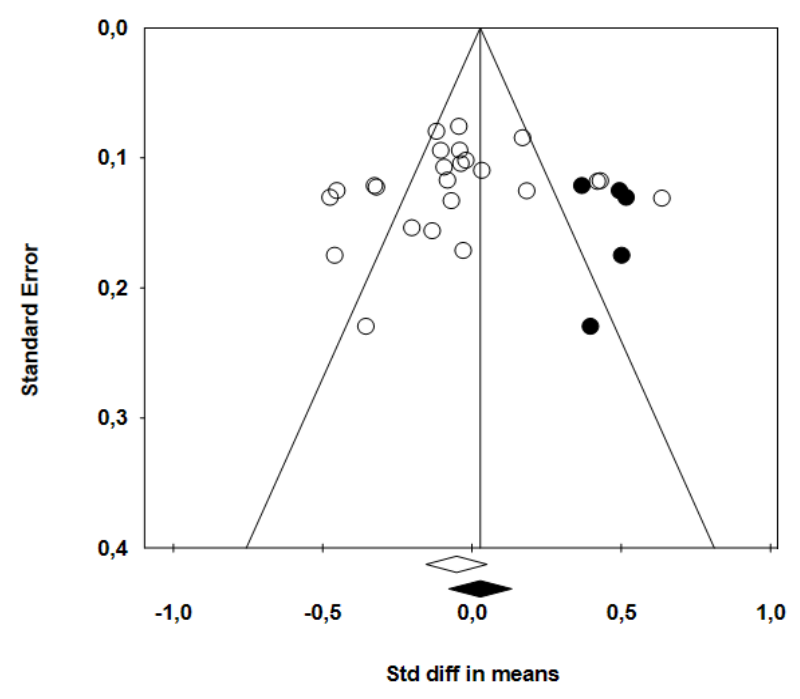

Figure $4 \mathbf{b}$. Teacher self-efficacy perception funnel graph for trim and fill method

In Figure 4a, the effect sizes of the studies about teacher self-efficacy perception and their standard errors are represented by circles. It is seen that the expected symmetrical distribution is partially achieved. It is seen that the effect sizes of the studies in favor of FE are smaller and closer to each other compared to the studies against FE, which prevents the appearance of full symmetry. For this reason, Figure 4 a cannot provide complete information about publication bias.

The black dots in Figure $2 \mathrm{~b}$ represent the publications that must be added to achieve full symmetry according to the trim and fill method of Duval and Tweedie (2000a, 2000b). The black equilateral quadrangle shows the overall effect size that will occur with the trim and fill method. When Figure $4 \mathrm{~b}$ is analyzed, if 5 publications, in favor of FE, are added to the analysis for corresponding coordinates the funnel plot will be fully symmetrical. The only number to be added to make the 24 studies fully symmetrical is only 5 , which is an indication that the current situation is close to symmetrical distribution. If these 5 studies are added, the overall effect will increase from -0.052 to 0.031 . The fact that the difference is small indicates that there is no publication bias in the studies. Egger's regression method (Egger, Davey Smith, Schneider, \& Minder, 1997), which is another method used in publication bias test, has $t$ value of 0.83 and $p$ value of 0.41 . A statistical significance value of $p>0.05$ indicates that there is no bias.

\section{DISCUSSION and CONCLUSION}

The aim of this study was to examine the singular study findings which comparing teacher candidates' attitudes towards teaching profession and teacher self-efficacy perceptions in terms of teacher training programs by using meta-analysis method. In accordance with this purpose, firstly, publication bias of studies, then the effect sizes related to attitudes towards the teaching profession and teacher self-efficacy perception in terms of teacher training programs are discussed.

Firstly, detailed scans were carried out to prevent bias that may occur in the literature review and the studies to be analyzed were selected with consensus. In the examination of the funnel graph method, there was no clear conclusion about the publication bias regarding both the attitude towards the teaching profession and the teacher self-efficacy perception studies. It was concluded that there was no publication bias for the studies according to trim and fill method of Duval and Tweedie, and the linear regression methods of Egger. 
When FE students are compared with the students in other programs, there are modest effect size findings that show that FE students have a more positive attitude than students in various programs and have a more negative attitude than others. When analyzed as a whole, it was found that FE students have a more negative attitude compared to other program students, the effect size is weak and not statistically significant. Similarly, in the meta-analysis study conducted by Atalmış and Köse (2018), it is stated that the attitudes of FE students do not differ significantly from the attitudes of PFCP and FSL students. Considering the above findings, it is seen that the attitudes of FE students towards the profession are not different from the students in the other programs, because those who have a more positive attitude and those with a more negative attitude balance each other. Although FE students' negative attitudes are not significantly different from other students' attitudes, it needs to be investigating deeply, since FE students have more negative attitudes towards the teaching profession, even though they choose their teaching programs to become teachers. It also points out that the adequacy of the selection application of students for FE teacher training programs and the content of the curriculum should be questioned. As a matter of fact, it is stated in some studies that FE freshman students have a more positive attitude than senior students (Çakmak \& Ercan, 2018). These findings indicate that FE teacher training programs may be inadequate in making students love the profession and gain a positive attitude.

When FE students' attitudes towards teaching profession are compared for each program, it is seen that the attitudes of faculty of education (FE) students are more positive than the students in physical education and sports teaching (PESS), faculty of theology (FT) and faculty of technical education (FTE). Considering Cohen's (Cohen, Manion, \& Morrison, 2007) effect size classification, it was found that the effect size of the difference was low for PESS and weak for FT and FTE, but all three effect sizes were not statistically significant. As with FE teaching programs, the purpose of PESS and FTE programs is to train teachers. Therefore, it is thought that PESS and FTE students prefer these programs to become teachers. Likely, the responsibility of training teachers for religious culture and moral knowledge teaching, and vocational courses in religious vocational high schools was given to FT. For this reason, FT students may also have preferred FT programs in order to become teachers. As a result, students in four programs may have similar attitude levels since they prefer their programs with the awareness of being and desire to become a teacher.

Several factors may have been influential in the attitude of PESS, FTE and FT students being more negative than FE students. For example, theology faculty students have other options besides being teacher, such as religious staff, teaching Quran (Korukçu, 2011). Similarly, PESS students work in various sports related professions other than teaching profession (Şaşmaz Ataçocuğu \& Zelyurt, 2017). Therefore, being a teacher is not seen as an indispensable option for these students. Lastly, negative attitudes of teacher candidates in FTE may be due to their low appointment probability (Çapri \& Çelikkaleli, 2008).

As a result of comparing the attitudes, it was found that attitudes towards the profession of teacher candidates at the Faculty of Science and Letters (FSL), Pedagogical formation education program (PFCP) and non-thesis master's degree program (NTMP) were more positive than the FE students. Considering the effect size classification of Cohen (Cohen, Manion, \& Morrison, 2007), the effect size was found to be meaningful only for PFCP students, and it has weak effect size. PFCP certificate program students consist of individuals who have graduated from undergraduate programs that do not have the aim to train teachers. Participants of studies took pedagogical formation lessons in order to be a teacher during the research studies period. This means that they decided to become teachers because they would have difficulties in finding a job related to their own graduation areas or they thought they made the wrong choice and they turned towards this path. As a matter of fact, it is stated that among the reasons 
for PFCP application, ease of finding a job and love of profession are the two most prominent reasons (Kiraz \& Dursun, 2015). PFCP students may be making more informed decisions because they are graduated and their age is getting older. In this regard, since they may be more willing and determined to be a teacher than FE students at the undergraduate level, they may have adopted a more positive attitude towards the teaching profession.

The teacher self-efficacy perceptions of FE students are more positive than some programs (FTE) and more negative than some programs (PFCP) and effect size is modest. When FE students were compared with all other programs as a whole, it was found that FE students' teacher self-efficacy perceptions were more negative, but the effect size of this difference was weak and statistically insignificant due to the different results in the opposite direction balancing each other. Since this finding will cause many data to be lost, a comparison was made on the basis of programs.

When FE and other programs were compared separately, it was found that teacher self-efficacy perceptions of FT and FTE students were lower than FE students. Considering the effect size classification of Cohen (Cohen, Manion, \& Morrison, 2007), the effect size of the difference seen between FE and FT was modest and significant, while the effect size of the difference between FE and FTE was weak and not significant.

Considering the related research sample shows that FT students have not taken the teaching practice course yet. They may feel inadequate for an unknown job, as they have not yet experience with the requirements of the profession. In addition, since the main purpose of FE teaching programs is to train teachers, it is stated that it is more likely to gain professional competence than FT students who aim to train theologians (Coşkun, 2011). In addition, many field courses at FE are carried out by associating them with the teaching profession. For example, the content of the community service course can be mostly student oriented. In short, FE instructors may have motivated their students to feel more proficient as they will have a better command of teaching profession lessons. Lastly, the fact that there is only one study in the FT sample included in the meta-analysis within the scope of this study requires a more cautious evaluation of the results.

On the other hand, self-efficacy perceptions of PESS, FSL, PFCP and NTMP students were found to be higher than FE students. Considering the effect size classification of Cohen (Cohen, Manion, \& Morrison, 2007), the effect size of the difference is significant only with NTMP and it was found to be modest.

When the findings are examined, there is only one study investigating NTMP students with higher self-efficacy perception than FE students, and it is noteworthy that this study was conducted with candidates of music teachers. For this reason, these features should be taken into consideration while generalizing. Despite this, various explanations can be made about why NTMP students feel more adequate. Firstly, since NTMP students are graduated, considering the date of the study maybe they performed their professions. It is stated that the teacher candidates - who are graduated - are currently teaching in various institutions (Baykara Özaydınlık, 2018). Therefore, it is possible that they will feel more competent because they have more experience. Another explanation is about whether the participants consider themselves realistic. As a matter of fact, PESS students who have a negative attitude towards the profession also consider themselves more adequate. In this context, since FE students evaluate themselves more realistically (Yalçın-İncik \& Kılıç, 2014), they may find themselves inadequate.

As a result, it is seen that FE students' attitudes towards teaching profession and their perceptions of teacher self-efficacy do not differ significantly than teacher candidates who are trained in other programs. However, when analyzed in detail on the basis of programs, it is seen 
that FE students' attitudes towards the profession are significantly lower than PFCP students and the effect size of this difference is weak. The teacher self-efficacy perceptions of FE students were significantly higher than FT students, but significantly lower than NTMP students. It is concluded that faculties of education whose main purpose is to train teachers do not increase these features of their students sufficiently. In the light of these findings, the following suggestions can be presented to researchers and practitioners:

Since there are not enough studies in the programs such as FT and PESS that continue to train teachers, more comparison studies can be conducted on this subject.

Although a holistic result has been revealed with meta-analysis, qualitative studies can be conducted to provide detailed data on different research results.

Interviews with FE students can be made and factors affecting their attitudes towards profession and perception of teaching self-efficacy can be determined.

Lecturers at FE can use various methods to help their students gain more teacher self-efficacy and more positive attitudes towards the profession.

This study has several strengths and limitations. The literature was scanned by two different researchers and the studies reached were carefully examined. In addition to the overall comparison of FE with other programs totally, extensive findings were presented by examining the comparisons FE with each program. The study has limitations since studies included are from Turkey sample. In addition, there is only one study in some programs, thus this is not suitable for the purpose of meta-analysis.

\section{Acknowledgements}

This research study was supported by Kahramanmaras Sutcu Imam University as a research project with 2018/2-48 number and extracted from this supported project.

\section{Declaration of Conflicting Interests and Ethics}

The authors declare no conflict of interest. This research study complies with research publishing ethics. The scientific and legal responsibility for manuscripts published in IJATE belongs to the author(s).

\section{ORCID}

İsmail YELPAZE (D) https://orcid.org/0000-0003-4428-0502

Levent YAKAR (iD https://orcid.org/0000-0001-7856-6926

\section{REFERENCES}

Akdemir, A. S. (2013). Türkiye'de öğretmen yetiştirme programlarının tarihçesi ve sorunları. Electronic Turkish Studies, 8(12) 15-28.

Arastaman, G. (2013). Eğitim ve fen edebiyat fakültesi öğrencilerinin öz-yeterlik inançları ve öğretmenlik mesleğine karşı tutumlarının incelenmesi. Ahi Evran Üniversitesi Kırşehir Ĕ̈itim Fakültesi Dergisi (KEFAD), 14(2), 205-217.

Atalmış, E., \& Köse, A. (2018). Türkiye'deki öğretmen adaylarının öğretmenlik mesleğine yönelik tutumları: Bir meta-analiz çalışması. Journal of Measurement and Evaluation in Education and Psychology, 9(4), 393-413.

Bağçeci, B., Yıldırım, İ., Kara, K., \& Keskinpalta, D. (2015). Pedagojik formasyon ve eğitim fakültesi öğrencilerinin öğretmenlik mesleğine yönelik tutumlarının karşılaştırılması. Erzincan Üniversitesi Eğitim Fakültesi Dergisi, 17(1), 307-324.

Bakioğlu, A., \& Göktaş, E. (2018). Bir eğitim politikası belirleme yöntemi: Meta analiz. Medeniyet Ĕ̈itim Araştırmaları Dergisi, 1(2), 35-54.

Bandura, A. (1997). Self- efficacy: The exercise of control. New York: Freeman 
Baykara Özaydınlık, K. (2018). A comparative analysis of preservice teachers' metacognitive learning strategies and teacher self-efficacy perceptions. Hacettepe University Journal of Education, 33(1), 125-143. https://doi.org/10.16986/HUJE.2017028409

Borenstein, M., Hedges, L. V., Higgins, J. P., \& Rothstein, H. R. (2009). Introduction to MetaAnalysis. UK: John Wiley \& Sons, Ltd.

Borenstein, M., Hedges, L. V., Higgins, J. P., \& Rothstein, H. R. (2010). A basic introduction to fixed effect and random effects models for meta analysis. Res. Synth. Method, 1, $97-$ 111. https://doi.org/10.1002/jrsm.12

Borenstein, M., Hedges, L. V., Higgins, J. P., \& Rothstein, H. R. (2013). Meta-analize giriş. (Çev. S. Dinçer). Ankara: Anı Yayıncılık.

Brown, A. L., Lee, J., \& Collins, D. (2015). Does student teaching matter? Investigating preservice teachers' sense of efficacy and preparedness. Teaching Education, 26(1), 77-93.

Canales, A., \& Maldonado, L. (2018). Teacher quality and student achievement in Chile: Linking teachers' contribution and observable characteristics. International Journal of Educational Development, 60, 33-50.

Cohen, J. (1990). Things I have learned (so far). American Psychologist, 45(12), 1304-1312

Cohen, L., Manion, L., \& Morrison, K. (2007). Research methods in education (6th ed.). New York, NY: Routledge.

Çakmak, M., \& Ercan, L. (2018). Öğretmen adaylarının öğretmenlik mesleğine ilişkin tutumları ve problem çözme becerilerinin incelenmesi. Ufuk Üniversitesi Sosyal Bilimler Enstitüsü Dergisi, 7(13), 29-43.

Çapa, Y., \& Çil, N. (2000). Öğretmen adaylarının öğretmenlik mesleğine yönelik tutumlarının farklı değişkenler açısından incelenmesi. Hacettepe Üniversitesi Eğitim Fakültesi Dergisi, 18(18), 69-73.

Çapri, B., \& Çelikkaleli, Ö. (2008). Öğretmen adaylarının öğretmenliğe ilişkin tutum ve mesleki yeterlik inançlarının cinsiyet, program ve fakültelerine göre incelenmesi. İnönü Üniversitesi Ĕ̈itim Fakültesi Dergisi, 9(15), 33-53.

Çelik, Ö. C., Koç Erdamar, G., \& Toraman, Ç. (2016). Gender differences in teachers and student teachers' self-efficacy beliefs: A Meta-Analysis. In E. Atasoy, R. Efe, I. Jażdżewska, \& H. Yaldır (Eds.), Current advances in education (pp: 587-602). Sofya: St. Kliment Ohridski University Press.

Çelik, S., Örenoğlu Toraman, S., \& Çelik, K. (2018). Öğrenci başarısının derse katılım ve öğretmen yakınlığıyla ilişkisi. Kastamonu Ĕ̆itim Dergisi, 26(1), 209-217. https://doi.org/10.24106/kefdergi.378129

Çetin, O. (2017). An investigation of pre-service science teachers' level of efficacy in the undergraduate science teacher education program and pedagogical formation program. Journal of Education and Practice, 8(12), 22-32.

Dadandı, İ., Kalyon, A., \& Yazıcı, H. (2016). Eğitim fakültesinde öğrenim gören ve pedagojik formasyon eğitimi alan öğretmen adaylarının öz-yeterlik inançları, kaygı düzeyleri ve öğretmenlik mesleğine karşı tutumları. Bayburt Eğitim Fakültesi Dergisi, 11(1), 253-269.

Dinçer, S. (2014). Ĕgitim bilimlerinde uygulamalı meta-analiz. Pegem Akademi.

Doğan, S. (2013). Sınıf ögretmenlerinin öz yeterlik algısı ve ögretmenlik mesleğine yönelik tutumlarının incelenmesi. Unpublished master's thesis. Erzincan Üniversitesi, Sosyal Bilimler Enstitüsü.

Durmuşoğlu, M. C., Yanık, C., \& Akkoyunlu, B. (2009). Türk ve Azeri öğretmen adaylarının öğretmenlik mesleğine yönelik tutumları. Hacettepe Üniversitesi Ĕ̆itim Fakültesi Dergisi, 36, 76-86.

Duval, S., \& Tweedie, R. (2000a). A nonparametric" trim and fill" method of accounting for publication bias in meta-analysis. Journal of the American Statistical Association, 95(449), 89-98. 
Duval, S., \& Tweedie, R. (2000b). Trim and fill: A simple funnel-plot-based method of testing and adjusting for publication bias in meta-analysis. Biometrics, 56(2), 455-463.

Egger, M., Davey Smith, G., Schneider, M., \& Minder, C. (1997). Bias in meta-analysis detected by a simple, graphical test. BMJ (Clinical research ed.), 315(7109), 629-634. https://doi.org/10.1136/bmj.315.7109.629

Ellis, P. D. (2010). The essential guide to effect sizes: Statistical power, meta-analysis, and the interpretation of research results. Cambridge, UK: Cambridge University.

Erdamar, G., Aytaç, T., Türk, N., \& Arseven, Z. (2016). The effects of gender on attitudes of preservice teachers towards the teaching profession: A meta-analysis study. Universal Journal of Educational Research, 4(2), 445-456.

Glass, G. V. (1976). Primary, secondary, and meta-analysis of research. Educational researcher, 5(10), 3-8.

Gülebağlan, C. (2003). Öğretmenlerin işleri son ana erteleme ĕgilimlerinin mesleki yeterlilik algıları, mesleki deneyimleri ve branşları bakımından karşılaştırılmasına yönelik bir araştırma. Unpublished master's thesis. Ankara Üniversitesi, Eğitim Bilimleri Enstitüsü, Ankara.

Higgins, J. P., Thompson, S. G., Deeks, J. J., \& Altman, D. G. (2003). Measuring inconsistency in meta-analyses. BMJ (Clinical research ed.), 327(7414), 557-560. https://doi.org/10.1136/bmj.327.7414.557

Hong, J., \& Greene, B. (2011). Hopes and fears for science teaching: The possible selves of preservice teachers in a science education program. Journal of Science Teacher Education, 22, 491-512.

İlter, İ. (2009). Öğretmen adaylarının öğretmenlik mesleğine ilişkin tutumlarının bazı değişkenler açısından incelenmesi (Unpublished master's thesis). Furat Üniversitesi, Sosyal Bilimler Enstitüsü, Elazığ.

Kağıtçıbaşı, Ç. (2013). Günümüzde insan ve insanlar. İstanbul: Evrim.

Karabıyık, B., \& Korumaz, M. (2014). Relationship between teacher's self-efficacy perceptions and job satisfaction level. Procedia-Social and Behavioral Sciences, 116, 826-830.

Kartal, O. Y., Temelli, D., \& Şahin, Ç. (2018). Ortaokul matematik öğretmenlerinin bilişim teknolojileri öz-yeterlik düzeylerinin cinsiyet değişkenine göre incelenmesi. Journal of Theoretical Educational Science, 11(4), 922-943.

Kaya, Z. (2001). Bir meslek olarak ögretmenlik ve ögretmenlik mesleğine giriş. Ankara: Pegem Akademi.

Kenrick, D. T., Neuberg, S. T., \& Cialdini, R. B. (2005). Social psychology: Unraveling the mystery (3th ed.). Boston, MA: Pearson.

Kiraz, Z., \& Dursun, F. (2015). Pedagojik formasyon eğitimi alan öğretmen adaylarının aldıkları eğitime ilişkin algıları. Mersin Üniversitesi Eğitim Fakültesi Dergisi, 11(3), 1008-1028. https://doi.org/10.17860/efd.37544

Korukçu, A. (2011). İlahiyat fakültesi son sınıf öğrencilerinin yaygın din eğitimine bakışları. Değerler Ĕgitimi Dergisi, 9(21), 55-97.

Lenhard, W., \& Lenhard, A. (2016). Calculation of effect sizes. Retrieved from https://www.psychometrica.de/effect_size.html. Dettelbach (Germany): Psychometrica.

Lipsey, M. W., \& Wilson, D. B. (2001). Practical meta-analysis. California: Sage Publications Milli Eğitim Bakanlığı, (2017). Öğretmenlik mesleği genel yeterlikleri. MEB Öğretmen Yetiştirme ve Eğitimi Genel Müdürlüğü. Ankara

Özden, Y. (1999). Ĕ̆itimde dönüşüm eğitimde yeni değerler. Ankara: Pegem A Yayınları

Özkan, H. H. (2012). Öğretmenlik formasyon programındaki öğretmen adaylarının öğretmenlik mesleğine ilişskin tutumlarının incelenmesi (SDU Örneği). Ahi Evran Üniversitesi Kırşehir Eğitim Fakültesi Dergisi (KEFAD), 13(2), 29-48. 
Recepoğlu, E. (2013). Öğretmen adaylarının yaşam doyumları ile öğretmenlik mesleğine ilişkin tutumları arasındaki ilişkinin incelenmesi. Hacettepe Üniversitesi Eğitim Fakültesi Dergisi, Special Issue (1), 311-326.

Sakallı, N. (2001). Sosyal etkiler: Kim, kimi nasil etkiler? Ankara: İmge.

Senemoğlu, N. (2012). Gelişim, ögrenme ve öğretim kuramdan uygulamaya. Ankara: Pegem Akademi.

Sullivan, G. M., \& Feinn, R. (2012). Using effect size-or why the p value is not enough. Journal of Graduate Medical Education, 4(3), 279-282. https://doi.org/10.4300/JGME-D-12$\underline{00156.1}$

Şaşmaz Ataçocuğu, M., \& Zelyurt, M. K. (2017). Spor bilimleri fakülteleri mezunlarının işsizlik deneyimleri üzerine nitel bir araştırma. Sportif Bakış: Spor ve Eğitim Bilimleri Dergisi, SI (1), 70-97.

Tschannen-Moran, M., Woolfolk-Hoy, A., \& Hoy, W. K. (1998). Teacher efficacy: Its meaning and measure. Review of Educational Research, 68, 202-248.

Tucker, C. M., Porter, T., Reinke, W. M., Herman, K. C., Ivery, P. D., Mack, C. E., \& Jackson, E. S. (2005). Promoting teacher efficacy for working with culturally diverse students. Preventing School Failure: Alternative Education for Children and Youth, 50(1), 29-34.

Tuncer, M. (2016). Evaluation of the attitude towards teaching profession in terms of gender through use of meta analysis method (A case study of Turkey). In E. Atasoy, R. Efe, I. Jażdżewska, \& H. Yaldır (Eds.), Current Advances in Education (pp. 587-602). Sofya: St. Kliment Ohridski University Press.

Üstün, U., \& Eryılmaz, A. (2014). Etkili araştırma sentezleri yapabilmek için bir araştırma yöntemi: Meta-analiz. Eğitim ve Bilim, 39(174), 1-32.

Yalçın-İncik, E., \& Kılıç, F. (2014). Attitudes regarding the teaching profession, professional efficacy beliefs and vocational self-esteem of teacher canditates enrolled at education faculties and pedagogic formation programmes. International Journal of Social Science and Education, 4(2), 380-391.

Yaşar Ekici, F. (2017). Okul öncesi öğretmen adayları ile pedagojik formasyon eğitimi alan öğretmen adaylarının öğretmenliğe yönelik öz yeterlik inançlarının karşılaştırılması. Journal of the Human and Social Sciences Researches, 6(5), 3003-3022.

Yıldırım, I., Çırak-Kurt, S., \& Şen, S. (2019). The effect of teaching "learning strategies" on academic achievement: A meta-analysis study. Eurasian Journal of Educational Research, 79, 87-114. https://doi.org/10.14689/ejer.2019.79.5 


\section{APPENDIX 1: Studies involved in Meta-Analysis}

Akça, F., Demir, S., \& Yılmaz, T. (2015). Öğretmen adaylarının özyeterlik algıları ile akademik kontrol odaklarının karşılaştırılması. Journal of Innovative Human Sciences, 2(1), 01-09. http://sproc.org/ojs/index.php/IJIRE

Aksoy, E. (2017). Turkish student teachers' attitudes toward teaching in university-based and alternative certification programs in Turkey. Asia Pacific Education Review, 18(3), 335346.

Atasoy, M. U. (2010). Lisans ve tezsiz yüksek lisans öğrenimi görmekte olan müzik ögretmeni adaylarının genel ögretmenlik öz yeterlik algılarının incelenmesi (Unpublished Doctoral Thesis). Gazi Üniversitesi Eğitim Bilimleri Enstitüsü, Ankara.

Bağçeci, B., Yıldırım, İ., Kara, K., \& Keskinpalta, D. (2015). Pedagojik formasyon ve eğitim fakültesi öğrencilerinin öğretmenlik mesleğine yönelik tutumlarının karşılaştırılması. Erzincan Üniversitesi Ë̆itim Fakültesi Dergisi, 17(1), 307-324.

Baykara Özaydınlık, K. (2018). A comparative analysis of preservice teachers' metacognitive learning strategies and teacher self-efficacy perceptions. Hacettepe University Journal of Education, 33(1), 125-143. https://doi.org/10.16986/HUJE.2017028409

Boran, M., \& Yanpar Yelken, T. (2018). Eğitim fakültesi ile pedagojik formasyon öğrencilerinin öğretmenlik mesleğine yönelik duyarlılıklarının ve etkili öğretmen özelliklerinin incelenmesi. Uluslararası Sosyal Bilimler Eğitimi Dergisi, 4(2), 144-164.

Bozkırlı, K. Ç., \& Er, O. (2011). Türkçe ve Türk dili ve edebiyatı öğretmeni adaylarının öğretmenlik mesleğine ilişkin tutumlarının çeşitli değişkenler açısından incelenmesi (Kafkas Üniversitesi örneği). Turkish Studies International Periodical for the Languages, Literature and History of Turkish or Turkic, 6(4), 457-466.

Coşkun, M. K. (2011). Din kültürü öğretmen adaylarının öğretmenlik mesleğine yönelik tutumları: İlahiyat-Eğitim DKAB karşılaştırması. EKEV Akademi Dergisi, 15(48), 269279.

Çakmak, M., \& Ercan, L. (2018). Öğretmen adaylarının öğretmenlik mesleğine ilişkin tutumları ve problem çözme becerilerinin incelenmesi. Ufuk Üniversitesi Sosyal Bilimler Enstitüsü Dergisi, 7(13), 29-43.

Çapri, B., \& Çelikkaleli, Ö. (2008). Öğretmen adaylarının öğretmenliğe ilişkin tutum ve mesleki yeterlik inançlarının cinsiyet, program ve fakültelerine göre incelenmesi. İn̈nü Üniversitesi Eğitim Fakültesi Dergisi, 9(15), 33-53.

Çelen, A., \& Eskicioglu, Y. (2015). özel yetenek sinavı ile öğrenci alan öğretmenlik bölümlerinde öğrenim gören öğrencilerin mesleğe yönelik tutum ve durumluk-sürekli kayg1 düzeylerinin incelenmesi. Route Educational and Social Science, 2(3), 1-18.

Çetin, O. (2017). An investigation of pre-service science teachers' level of efficacy in the undergraduate science teacher education program and pedagogical formation program. Journal of Education and Practice, 8(12), 22-32.

Dadandı, İ., Kalyon, A., \& Yazıcı, H. (2016). Eğitim fakültesinde öğrenim gören ve pedagojik formasyon eğitimi alan öğretmen adaylarının öz-yeterlik inançları, kaygı düzeyleri ve öğretmenlik mesleğine karşı tutumları. Bayburt Ĕ̆itim Fakültesi Dergisi, 11(1), 253-269.

Deniz, S. (2013). Öğretmen adaylarının öğrenme stilleri ve öğretmen öz-yeterlik alg1 düzeylerinin bazı değişkenler açısından incelenmesi. International Online Journal of Educational Sciences, 5(3), 667-684.

Elkatmış, M., Demirbaş, M., \& Ertuğrul, N. (2013). Eğitim fakültesi öğrencileri ile formasyon eğitimi alan fen edebiyat fakültesi öğrencilerinin öğretmenlik mesleğine yönelik öz yeterlik inançları. Pegem Ĕgitim ve Öğretim Dergisi, 3(3), 41-50. 
Ilgaz, G., Bülbül, T., \& Çuhadar, C. (2013). Öğretmen adaylarının eğitim inançları ile özyeterlik algıları arasındaki ilişkinin incelenmesi. Abant İzzet Baysal Üniversitesi Eğitim Fakültesi Dergisi, 13(1), 50-65.

İpek, C., \& Demirel, İ. N. (2012). Sınıf öğretmenliği ve pedagojik formasyon programı öğretmen adaylarının öğretmen özyeterlik inançları. Bayburt Üniversitesi Ĕgitim Fakültesi Dergisi, 7(1), 54-67.

Gedik, Z. G. (2015). Öğretmen özyeterlik algısı ölçeğinin psikometrik özelliklerinin ĕgitim fakültesinden mezun olan ve olmayan ögretmen adaylarl gruplarında incelenmesi (Unpublished Master Thesis). Abant İzzet Baysal Üniversitesi Eğitim Bilimleri Enstitüsü, Bolu.

Gürbüz, H., \& Kışoğlu, M. (2007). Tezsiz yüksek lisans programına devam eden fen edebiyat ve eğitim fakültesi öğrencilerinin öğretmenlik mesleğine yönelik tutumları (Atatürk Üniversitesi Örneği). Erzincan Ĕ̈itim Fakültesi Dergisi, 9(2), 71-83.

Gürbüztürk, O., \& Şad, S. N. (2009). Student teachers? beliefs about teaching and their sense of self efficacy: A descriptive and comparative analysis. İönü Üniversitesi Ĕ̈itim Fakültesi Dergisi, 10(3), 201-226.

Kabaday1, M., Bostanc1, Ö., Atan, T., Yazıcı, M., \& Evli, F. (2011). Eğitim fakülteleri ile beden eğitimi ve spor yüksek okullarında okuyan öğretmen adaylarının öğretmenlik mesleğine karşı tutumlarının incelenmesi. Türkiye Kickboks Federasyonu Spor Bilimleri Dergisi, 4(2). Retrieved from http://edergi.kickboks.gov.tr/media/Dosya/yayin/07/2.doc

Keskin, Y. (2017). Coğrafya öğretmen adaylarının öğretmenlik mesleğine yönelik tutum ve kayg1 düzeyleri (Erzurum Örneği). e-Kafkas Eğitim Araştırmaları Dergisi, 4(2), 43-57.

Ömür, Y. E., \& Nartgün, Ş. S. (2013). Öğretmen adaylarının öğretmenlik mesleğine ilişkin tutumları ile güdülenme düzeyleri arasındaki ilişki. Eğitimde Politika Analizi Dergisi, 2(2), 41-55.

Özgür, N. F. (1994). Öğretmenlik mesleğine kaşı tutum (Unpublished Doctoral Thesis), Marmara Üniversitesi Sosyal Bilimler Enstitüsü, İstanbul

Polat, S. (2013). Pedagojik formasyon sertifika programı ve eğitim fakültesi öğrencilerinin öğretmenlik mesleğine yönelik tutumlarının incelenmesi. e-Uluslararası Eğitim Araştırmaları Dergisi, 4(2), 48-60.

Poyraz, C., \& Çağırgan Gülten, D. (2014). Pre-service mathematics teachers' attitudes towards the profession of teaching. International Online Journal of Educational Sciences, 6(3), 558-569.

Sandıkçı, M., \& Öncü, E. (2013). Beden eğitimi ile diğer alanlardaki öğretmen adaylarının öğretmenlik mesleğine ilişkin yeterlik algıları ve tutumlarının belirlenmesi ve karşılaştırılması. Pamukkale Journal of Sport Sciences, 4(1), 135-151.

Sezer, A., Pınar, A., \& Yıldırım, T. (2010). Coğrafya öğretmeni adaylarının bazı profil özellikleri ve öğretmenlik mesleğine yönelik tutumlarının incelenmesi. Marmara Coğrafya Dergisi, (22), 43-69.

Taşgın, A. (2018). Öğretmen adaylarının öğretmenlik mesleğine ilişkin tutumları ile mesleki özyeterlikleri arasındaki ilişkinin incelenmesi. In A. İşcan, (Ed.), Ĕgitim Bilimlerinde Örnek Araştırmalar (pp. 87-105). Ankara: Nobel.

Timur, B., \& İmer Çetin, N. (2017). Examining self-efficacy beliefs and attitudes of pre-service science teachers' and pedogogical proficiency students' towards science teaching profession. International Journal of Active Learning, 2(2), 15-27.

Uygun, S. (2016). Pedagojik formasyon ve eğitim fakültesi öğrencilerinin öğretmenlik mesleğine yönelik duyarlıklarının karşılaştırılması. Ahi Evran Üniversitesi Kırşehir Eğitim Fakültesi Dergisi (KEFAD), 17(1), 313-330. 
Ürün Karahan, B. (2017). Türkçe öğretmenliği ve Türk dili ve edebiyatı bölümü öğrencilerinin yaşam boyu öğrenme eğilimlerinin mesleğe yönelik tutumları ile ilişkisi. e-Kafkas Eğitim Araştırmaları Dergisi, 4(3), 30-44.

Yakar, L., \& Yelpaze, İ. (2019). Öğretmen yetiştiren programlara kayıtlı öğrencilerin öğretmenlik mesleğine yönelik tutumları ve öğretmen öz-yeterlik algıları. Pamukkale Üniversitesi Ĕ̈itim Fakültesi Dergisi, 47, 107-129. https://doi.org/10.9779/pauefd.4736 $\underline{78}$

Yalçın-İncik, E., \& K1lıç, F. (2014). Attitudes regarding the teaching profession, professional efficacy beliefs and vocational self-esteem of teacher canditates enrolled at education faculties and pedagogic formation programmes. International Journal of Social Science and Education, 4(2), 380-391.

Yaşar Ekici, F. (2017). Okul öncesi öğretmen adayları ile pedagojik formasyon eğitimi alan öğretmen adaylarının öğretmenliğe yönelik özyeterlik inançlarının karşılaştırılması. Journal of the Human and Social Science Researches, 6(5), 3003-3022.

Yavuz, M. (2010). An analyze of teacher candidate students' perception of self efficacy. Procedia-Social and Behavioral Sciences, 2(2), 1394-1398. 